\title{
Measuring the Frequency of Critical Thinking in a Second Language Academic Discussion Course
}

\author{
Samuel Reid, Ph.D. ${ }^{1} \&$ Travis West, M.A. ${ }^{2}$ \\ ${ }^{1,2}$ Foreign Language Education and Research Center, Rikkyo University, Japan \\ 1 (i)/0000-0002-5065-4219 \\ 2 (D)/0000-0002-1238-7703
}

DOI: https://dx.doi.org/10.46679/978819484836309

Abstract

As technology and globalization increase the chances of exposure to information, learners' Critical Thinking (CT) and researchers' ability to measure it will play an important role in developing modern educational experiences. This is particularly the case for English language learners who wish to enter tertiary education in English-speaking countries (Liaw, 2007; Wagner, 2010). Emphasis on such skills is increasingly a facet of language education in Japanese contexts. This can be seen in changes implemented by the Japan Ministry of Education, Culture, Sports, Science, and Technology which have encouraged a focus on CT in English language courses during recent years (MEXT, 2011). However, it can be difficult for second language (L2) learners to exhibit CT in an L2 (Bali, 2015; Luk \& Lin, 2015). Measuring CT in learner output has also proven difficult, which can be an obstacle to further integrating CT in L2 pedagogy. Studies exploring ways of measuring CT in an L2 have largely focused on written work (e.g., Davidson \& Dunham, 1997; Floyd, 2011; Stapleton, 2001), while analysis of CT in spoken L2 discourse has seen little attention. As a result, little advice can be found on practical steps for teachers to help learners display CT when speaking in an L2.

This chapter describes a study of arguments made during group discussions in an L2 English Discussion course at a Japanese university. 
A corpus of spontaneous spoken discourse recorded during class was analyzed to measure the frequency of $\mathrm{CT}$ displayed in an academic setting where CT was not an explicit focus of the course. Arguments in the corpus were identified using Ramage et al.'s (2016) model of argument criteria, and a categorization system was developed in which discourse was classified as displaying either objective reasoning or subjective reasoning. Participants were found to have used approximately $72 \%$ objective and $28 \%$ subjective reasoning. However, further analysis revealed an important qualitative difference in arguments identified as incorporating objective reasoning. The results of the study suggest two areas that may help teachers promote an increase in student usage of $\mathrm{CT}$ : the importance of question prompts in orienting learners towards CT in their answers, and a specific focus on the role of pronoun usage in taking a subjective or objective stance.

Keywords: Higher-order thinking skills, pronoun usage, corpus linguistics, argumentation

\section{Introduction}

Critical thinking (CT) is fundamental to modern educational experiences. It is widely agreed $\mathrm{CT}$ should be a major, if not the ultimate, the aim of higher education (Davies, 2006; Ikuenobe, 2001; Moore, 2011). The ability to think critically is necessary for success in contemporary knowledge-based societies and for participation in the globalized economy. Modern educators have a responsibility to help learners with these skills, and as Liaw (2007) argues, this means EFL teachers have a responsibility not just to teach language, but to help their learners acquire CT skills. For educators to carry out this task, they need information regarding their learners' CT needs. As Floyd (2011) points out, if instruction on CT is to be successful, teachers need to understand not only what their learners' CT limitations maybe, but also the reason for them. Previous research measuring CT in an L2 is 


\section{This is a limited preview of the chapter.}

To read the full-text chapter, get access by purchasing this chapter or consider buying the complete book. If your library has subscription to EBSCOhost, the chapter including other chapters of the book can be accessed through your library.

This chapter is a part of the book, 'Development of Innovative Pedagogical Practices for a Modern Learning Experience' ISBN (paperback): 978-81948483-6-3; ISBN (ebook): 978-81-948483-7-0

Book DOI: https://dx.doi.org/10.46679/9788194848363

Available via CSMFL Bookstore, Amazon, Google Play Books, EBSCOhost \& EBSCO eBooks 
classes with CT as a goal should not underestimate the possible influences of pronouns as demonstrated in our data.

While our approach to identifying CT as objective or Subjective is broad, it helped highlight two influences on the display of CT which we believe could be easily addressed in the classroom. Awarenessraising of academic expectations and the effect of pronoun use are simple steps appropriate to almost all levels of learner. One extension of the present study would be a comparison between this corpus and a treatment group receiving $\mathrm{CT}$ instruction.

While challenges identifying arguments in spontaneous spoken learner discourse persist, this area of inquiry remains underexplored despite its possible contributions to understanding CT in academic discussions. We encourage other researchers to adapt and refine our coding system and add to this valuable field of inquiry.

\section{Acknowledgement}

The authors would like to express their gratitude to Tim Opitz and Jonathan Buck for permission to use the REDC Corpus for this study.

\section{References}

Adolphs, S., \& Knight, D. (2010). Building a spoken corpus: What are the basics? In A. O'Keeffe \& M. McCarthy (Eds.), The Routledge handbook of corpus linguistics (pp. 38-52). Routledge.

Alagozlu, N. (2007). Critical thinking and voice in EFL writing. The Asian EFL Journal Quarterly, 9(3), 118-136.

Anthony, L. (2018). AntConc (Version 3.5.7) [Computer Software].

Waseda University. http://www.laurenceanthony.net/software Bailin, S. (1995). Is critical thinking biased? Clarifications and implications. Science \& Educational Theory, 45(2), 191-197. https://doi.org/10.1111/j.1741-5446.1995.00191.x 
Bali, M. (2015). Critical Thinking through a multicultural lens: Cultural challenges of teaching critical thinking.In M. Davies\&R. Barnett (Eds.), The Palgrave Handbook of Critical Thinking in Higher Education (pp. 317-334). Macmillan.

Barnawi, O. Z. (2011). Finding a place for critical thinking and selfvoice in college English as a foreign language. Writing Classrooms, 4(2), 190-197.

Benesch, S. (1999). Thinking critically, thinking dialogically. TESOL Quarterly, 33(3), 573-580. https://doi.org/10.2307/3587682

Buck, J. (2017). Developing the Rikkyo English discussion corpus. In G. Brooks (Ed.), The 2016 PanSIG Journal (pp. 25-30).JALT.

Chirgwin, S. K., \& Huijser, H. (2015).Cultural variance, critical thinking, and indigenous knowledges: Exploring a both-ways approach. In M. Davies \& R. Barnett (Eds.), The Palgrave handbook of critical thinking in higher education. (pp. 335-350). Macmillan.

Crammond, J. G. (1998). The uses and complexity of argument structures in expert and student persuasive writing. Written Communication, 15, 230-268. https://doi.org/10.1177/0741088398015002004

Crosthwaite, P., Boynton, A., \& Cole, S. (2017). Exploring rater conceptions of academic stance and engagement during group tutorial discussion assessment. Journal of English for Academic Purposes, 28, 1-13. https://doi.org/10.1016/j.jeap.2017.04.004

Davidson, B. W., \& Dunham, R. A. (1997). Assessing EFL student progress in critical thinking with the Ennis-Weir Critical Thinking Essay Test. JALT Journal, 19(1), 43-57. http://jaltpublications.org/jj/articles/2704-assessing-efl-studentprogress-critical-thinking-ennis-weir-critical-thinking-essay

Davies, W. M. (2006). An 'infusion' approach to critical thinking: Moore on the critical thinking debate. Higher Education Research \& Development, 25(2), 179-193. DOI: 10.1080/07294360600610420 
Davies, M., \& Barnett, R. (2015). The Palgrave handbook of critical thinking in higher education. Macmillan.

Ennis, R. H. (2011). The nature of critical thinking: An outline of critical thinking dispositions and abilities. https://education.illinois.edu/docs/default-source/facultydocuments/robertennis/thenatureofcriticalthinking_51711_000.pdf?sfvrsn=7bb512 88_2

Facione, P. A. (1990). Critical thinking: A Statement of expert consensus for purposes of educational assessment and instruction. https://files.eric.ed.gov/fulltext/ED315423.pdf

Fisher, A. (2011) Critical thinking - An introduction. (2nd ed.). Cambridge University Press.

Floyd, C. B. (2011). Critical thinking in a second language. Higher Education Research \& Development, 30(3), 289-302. https://doi.org/10.1080/07294360.2010.501076

Gunter, K. K. (2011). Braiding and rhetorical power players: Transforming academic writing through rhetorical dialectic. Journal of Basic Writing, 30(1), 64-98. DOI: 10.37514/JBWJ.2011.30.1.04

Ikuenobe, P. (2001). Teaching and assessing critical thinking abilities as outcomes in an informal logic course. Teaching in Higher Education, 6(1), 19-32. DOI: 10.1080/13562510020029572

Liaw, M. (2007). Content-based reading and writing for critical thinking skills in an EFL context. English Teaching \& Learning, 31(2), 45-87. https://citeseerx.ist.psu.edu/viewdoc/download?doi=10.1.1.580. 288\&rep=rep $1 \&$ type $=$ pdf

Luk, J., \& Lin, A. (2015). Voices without words: Doing critical literate talk in English as a second language. TESOL Quarterly, 49(1), 6791.DOI: 10.1002/tesq.161 
McEnery, T., Xiao, R., \& Tono, Y. (2006). Corpus-based language studies: An advanced resource book. Routledge.

Mehta, S. R., \& Al-Mahrooqi, R. (2015). Can thinking be taught? Linking critical thinking and writing in an EFL context. RELC Journal, 46(1), 23-36. https://doi.org/10.1177/0033688214555356

MEXT. (2011). Koutougakkou gakushuushidouyouryou [The course of study for foreign languages for senior high school], provisional English version. Retrieved from http://www.mext.go.jp/a_menu/shotou/newcs/youryou/eiyaku/_icsFiles/afieldfile/2011/04/11/1298353_9. pdf

Moon, J. (2008). Critical thinking: An exploration of theory and practice. Routledge.

Moore, T. J. (2011). Critical thinking and language: The challenge of generic skills and disciplinary discourses. Continuum.

Morikawa, S., Harrington, L., \& Shiina, K. (2012). Critical thinking in a Japanese university current affairs course. Papers on Languages and Culture, (6), 117-113. https://www.cphe.chibau.jp/ge/activity/archive/pdf/plc06-09.pdf

Nunn, R., \& Caroline Brandt, C. (2016) A phenomenological approach to teaching reflective writing. English Scholarship Beyond Borders, 2(1), 130-151. http://englishscholarsbeyondborders.org/wpcontent/uploads/2016/02/Roger-Nunn-and-CarolineBrandt.pdf

Opitz, T. A. (2016). The efficacy of drilling backchannels in a CLT context: A corpus analysis of Japanese ESL learners. New Directions in Teaching and Learning English Discussion, 4(1), 200-210. Opitz, T. A. (2017). Tracking lexical development in the EDC classroom: RED corpus study \#2. New Directions in Teaching and Learning English Discussion, 5(1), 208-214.

Paul, R., \& Elder, L. (1996). Using intellectual standards to assess student reasoning. Retrieved September 6, 2006, from 
http://www.criticalthinking.org/resources/ TRK12-usingintellectual-standards.shtml

Paul, R., \& Elder, L. (2008). Defining critical thinking.

https://www.criticalthinking.org/pages/defining-criticalthinking/766

Possin, K. (2014). Critique of the Watson-Glaser Critical Thinking Appraisal Test: The more you know, the lower your score. Informal Logic, 34(4), 393416.https://doi.org/10.22329/il.v34i4.4141

Ramage, J. D., Bean, J. C., \& Johnson, J. (2016). Writing arguments: A rhetoric with readings (10thed.). Pearson.

Rear, D. (2012). The dilemma of critical thinking: Conformism and nonconformism in Japanese education policy. In T. Isles \&P. Matanle (Eds.), Researching twenty-first century Japan: New perspectives for the electronic age (pp. 119-137). Lexington Books.

Shea, D. P. (2018). Trying to teach dialogically: The good, the bad, and the misguided. Language Teaching Research, 23(6), 1-18. DOI:10.177/1362168818768982

Sinclair, J. (2005). Corpus and text-basic principles. In M. Wynne (Ed.), Developing linguistic corpora: A guide to good practice (pp. 1-16). Oxbow Books.

Stapleton, P. (2001). Assessing critical thinking in the writing of Japanese university students: Insights about assumptions and content familiarity. Written Communication, 18(4), 506-548. DOI: https://doi.org/10.1177/0741088301018004004

Stroupe, R. R. (2006). Integrating critical thinking throughout ESL curricula. TESL Reporter, 39(2), 42-61.

Toulmin, S. (2003). The uses of argument. Cambridge University Press.

Tsuruta, Y. (2013). The knowledge society and the internationalization of Japanese higher education. Asia Pacific Journal of Education, 33(2), 140-155. http://dx.doi.org/10.1080/02188791.2013.780674 
Wagner, T. (2010). The global achievement gap: Why even our best schools don't teach the new survival skills our children need - And what we can do about it. Basic Books.

\section{About the authors}

Samuel Reid has been an academic English instructor at universities in Tokyo for 17 years. He has a Ph.D. in Applied Linguistics from the University of Birmingham. His research interests are the critical discourse analysis of representations of agency and the testing and development of critical thinking in a second language.

Travis West has taught academic English in both South Korea and Japan and has held a position at a university in Tokyo for the last seven years. Travis has an M.A. in Applied Linguistics and TESOL from the University of Leicester. His research interests include critical thinking in a second language, corpus linguistics, and curriculum development in task-based language teaching. 
